\title{
AGE AND PALYNOLOGICAL CHARACTERISTICS OF FLOODPLAIN DEPOSITS OF THE KOLYMA LOWLAND (North-East Siberia)
}

\author{
A. V. Lozhkin', P. M. Anderson ${ }^{2}$ \\ ${ }^{I}$ North-East Interdisciplinary Scientific Research Institute n. a. N. A. Shilo, FEB RAS, Magadan \\ ${ }^{2}$ Quaternary Research Center, University of Washington, Seattle WA, USA \\ E-mail: lozhkin@neisri.ru,pata@uw.edu
}

\begin{abstract}
River floodplains, reaching several kilometers in width, are one of the main landscape features of the Kolyma Lowland. Their relationship with other forms of relief - yedoma, alasses, and fragments of river terraces - is seen clearly in the Bolshaya Kuropatoch'ya River basin, which is located in the Lowland between $156^{\circ} 30^{\prime} \mathrm{E}$ and $157^{\circ} 15^{\prime} \mathrm{E}$. The first radiocarbon dating of the floodplain deposits of the Kolyma Lowland was undertaken in a study of an outcrop on the left bank of the Bolshaya Kuropatoch'ya River $\left(71^{\circ} 40^{\prime} \mathrm{N}, 156^{\circ} 45^{\prime} \mathrm{E}\right)$. Here floodplain sediments, represented by the alternating layers of alluvial silt and peat with a total thickness of $5 \mathrm{~m}$, were exposed along a steep bank of an oxbow lake. The radiocarbon results show that the formation of the modern floodplain of the Bolshaya Kuropatoch'ya River began at the end of the Middle Holocene and continued during the Late Holocene to the present. Since the vegetation cover of arctic and subarctic regions is characterized by low pollen productivity, the spore-pollen spectra of modern and fossil plant communities often include an increased amount of pollen from plant species exotic to the Arctic, brought to the site by long-distance wind transport. For a more reliable interpretation of the sporepollen spectra of the floodplain sediments, an analysis of the modern vegetation in the Bolshaya Kuropatoch'ya River basin and in a coastal area bordering the East Siberian Sea (about $71^{\circ} 05^{\prime} \mathrm{N}$ ) was carried out, accompanied by an herbarium collection. The radiocarbon-dated palynological data indicate the development of the modern Betula-Salix shrub-herbaceous tundra during the second half of the Holocene. The establishment of this vegetation community reflects the replacement of an earlier Betula forest-tundra, which had prevailed in the northern regions of Western Beringia during the Early Holocene and included Duschekia fruticosa and large shrub species of Salix. Such dramatic changes in the vegetation cover were associated with the rise in sea level about 7.000-6.000 years ago, when seas approached modern levels. This change, in turn, led to a decrease in the contrast of summer and winter temperatures and, thus, to a decrease in the continentality of the climate and a significant reduction in the growing season in the coastal regions of the East Siberian Sea.
\end{abstract}

Keywords: Holocene, floodplain, meander, oxbow lake, sediments, radiocarbon, palynology, vegetation.

DOI: 10.34078/1814-0998-2021-3-56-62

The Kolyma Lowland is an extensive area of flat relief located in northeastern Asia. It stretches for $750 \mathrm{~km}$ between the Alazey and the Yukagir Ranges, and spans the basins of the Kolyma, Alazeya and Bolshaya Chukoch'ya Rivers. The Kolyma Lowland is also considered to be the eastern part of the East Siberian Lowland. The Lowland is characterized by minor variations in elevation, typically between 25 $100 \mathrm{~m}$ but with small hills of up to $300 \mathrm{~m}$. Permafrost and related thermokarst processes result in local changes in relief such as small depressions, pingos, and frost cracks.

The modern-day surfaces of the Kolyma Lowland, with absolute elevations between $25 \mathrm{~m}$ (near the coast of the East Siberian Sea) and $100 \mathrm{~m}$ (in the foothills), are underlain by an ice-rich silt, which includes ice

C) Lozhkin A. V., Anderson P. M., 2021 wedge polygons. These sediments are often referred to as the "ice complex". The total ice content in these deposits is $60-80 \%$. Interfluvial areas are eroded or "eaten" by thermokarst processes, which is why the landforms and associated sediments are called "yedoma" (derived from the Russian word for "eating"). The ice stratum is also known as the Yedoma Formation. As a result of thermokarst erosion, hills or massifs of yedoma and thermokarst basins, the latter known as alasses, alternate across the Lowland landscape. In some places, thermokarst processes have led to the emergence of vast alass plains (Kaplina and Lozhkin, 1979).

The presence of numerous thermokarst lakes is very characteristic for both the Kolyma Lowland, as well as for all the Primorye Lowlands of SakhaYakutia (Yana-Indigirka Lowland). Some of these lakes obtain lengths up to $15-19.5 \mathrm{~km}$ and widths of 
$10.5 \mathrm{~km}$ in width (Ilirgytgyn Lake, Bolshoye Morskoye Lake in the eastern part of the Lowland). Thermokarst lakes further shape the Lowland landscapes, because these water bodies can "migrate", resulting in the merger of lakes or draining of the basins.

River floodplains, which can be up to several kilometers wide, are a main component of the relief in the Kolyma Lowland. When the rivers overflow, the waters carry sands and silts (often with plant remains), which are deposited across the floodplain. The accumulation of sediments gradually increases the level of the floodplain surface. Simultaneously with the accumulation of sediments on the surface of the floodplain, an undermining of the bordering banks by the river flow can occur in some areas, whereas in other parts the build-up of beaches takes place, resulting in the constant change of floodplain configuration.

The floodplain microrelief is characterized by polygon tundra dotted with numerous bogs. The rivers crossing the Kolyma Lowland and flowing into the East Siberian Sea actively meander across the wide floodplain, and in the process destroy the high surface (formed by the yedoma) of the tundra. When the direction of the channel changes, the river can join with a previously formed meander. In this case, a "ring" lake appears, which gradually develops into an oxbow lake.

The relationship of various forms of relief in the Kolyma Lowland (i.e., yedoma with its characteristic hidden polygons and ice wedges, alasses, fragments of river terraces, floodplains) is clearly observed in the Bolshaya Kuropatoch'ya River basin, which crosses the lowland in the meridional direction between $156^{\circ} 30^{\prime} \mathrm{E}$ and $157^{\circ} 15^{\prime} \mathrm{E}$. The source of the river is located within the Lowland at about $70^{\circ} 08^{\prime} 59^{\prime \prime} \mathrm{N}$ and $155^{\circ} 24^{\prime} 48^{\prime \prime} \mathrm{E}$, with an elevation of $28 \mathrm{~m}$ at the headwaters. An estuary is formed at the mouth of the river $\left(71^{\circ} 03^{\prime} 55^{\prime \prime} \mathrm{N}, 156^{\circ} 35^{\prime} 11^{\prime \prime} \mathrm{E}\right)$ where it flows into the East Siberian Sea. The river is $391 \mathrm{~km}$ long; the catchment encompasses $6240 \mathrm{~km}^{2}$. The river system is fed by snow melt and rain (Fig. 1).

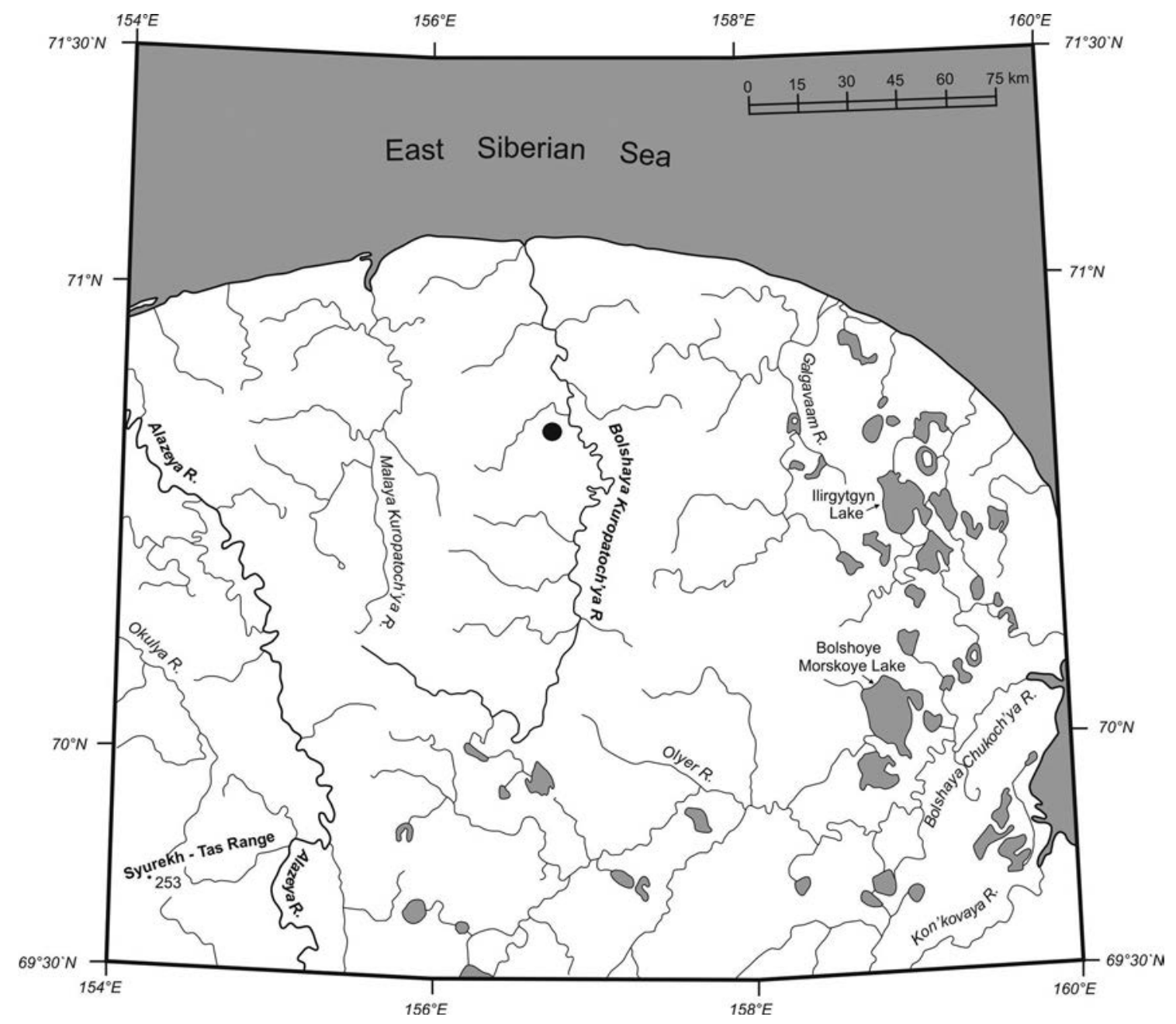

Fig. 1. Location of the Bolshaya Kuropatoch'ya River basin; black circle - the location of the exposure of the floodplain sediments in the steep bank of the oxbow lake

Puc. 1. Географическое положение бассейна р. Большая Куропаточья; черный кружок - местонахождение обнажения осадков поймы в обрывистом берегу старичного озера 
Vegetation of the Bolshaya Kuropatoch'ya River basin belongs to the subzone of moss-lichenSalix tundra and is characterized by a depauperate vegetation. Graminoids and forbs dominate areas along the riverbeds near the edge of the floodplain, on river terraces, and in the bottoms of drained lakes. On the banks of the rivers and lakes, Salix thickets are common. Towards the coast, the shrubs become increasingly stunted in growth and are gradually replaced by prostrate forms of Salix reptans and $S$. pulchra. Betula exilis is found, albeit rarely, in the vegetation beginning approximately $20 \mathrm{~km}$ south of the East Siberian Sea.

Since radiocarbon dating and palynological analysis of the floodplain sediments of the Kolyma Lowland had not been carried out previously, an outcrop located in the floodplain on the left bank of the Bolshaya Kuropatoch'ya River $\left(71^{\circ} 40^{\prime} \mathrm{N}\right.$, $\left.156^{\circ} 45^{\prime} \mathrm{E}\right)$ was investigated.

Here floodplain sediments were exposed in the steep bank of an oxbow lake. The visible thickness of sediments is 4 meters. However, the complete exposure is a 5-meter-thick deposit consisting of floodplain sediments, with the lower 1 meter of the section lying underwater. Layers of alluvial silt and peat alternate throughout the outcrop. Undoubtedly, the riverbed has changed its position many times in the past. Such shifts in the channel are indicated by the stabilized organic surfaces and by the organicpoor sediments that formed the riversides.

The lithology of the floodplain deposits in the Bolshaya Kuropatoch'ya exposure is as follows (from top to bottom): $0-20 \mathrm{~cm}$ - vegetation layer; $20-150 \mathrm{~cm}$ - bluish-gray sandy loam with interlayers of brownish organic residue (herbaceous plants); 150 $270 \mathrm{~cm}$ - brown autochthonous peat; $270-310 \mathrm{~cm}$ bluish-gray sandy loam with a layered, reticular cryotexture and numerous horizontal layers (1$2 \mathrm{~cm}$ thick) of plant remains; $310-340 \mathrm{~cm}$ - brown allochthonous peat with small twigs of shrubs and the remains of herbaceous plants; contains thin layers of organic material; $340-500 \mathrm{~cm}$ - bluish-gray, dense sandy loam with a lamellar mesh texture.

Bulk samples of peat were used for the first radiocarbon dating of the deposits of the Kolyma Lowland floodplain. Radiocarbon dating was done using the scintillation method. The dates obtained are: ${ }^{14} \mathrm{C}$ age $1.600 \pm 80$ years ago (median cal age 1.480 years ago) at a depth of $160 \mathrm{~cm},{ }^{14} \mathrm{C} 2.755 \pm$ 130 years ago (median cal age 2.890 years ago) at a depth of $260 \mathrm{~cm},{ }^{14} \mathrm{C}$ age $5180 \pm 300$ years ago (median cal age 5.940 years ago) at a depth of $330 \mathrm{~cm}$. These results show that the formation of the modern Bolshaya Kuropatoch'ya River floodplain most likely began in the latter part of the Middle Holocene (Walker et al., 2019), and that deposition has continued during the Late Holocene to the present.
Samples for palynological analysis were taken from the layers of sandy loam and peat and from the modern vegetation layer. The pollen and spore percentages were calculated and the pollen diagrams were constructed using TILIA and TILIAGRAPH (http://museum.state.il.us./pib/grimm/tilia). The individual pollen taxon is shown as a percentage of the total of all pollen grains, and spore taxa are shown as a percentage of the total pollen. The groups of trees and shrubs, subshrubs and herbaceous plants, and spores are shown on the left side of the diagram (Fig. 2). Their percentages are based on a sum of all pollen and spores. The pollen diagram indicates only minor changes in the spore-pollen spectra. The spectra are dominated by Betula (up to $20 \%$ ), Cyperaceae (up to $21 \%$ ), and Poaceae (up to $28 \%$ ) pollen. Taxa with lower but still significant percentages include Alnus (up to $10 \%$ ), Pinus subgen. Haploxylon (up to $7 \%$ ), Salix (up to $5 \%$ ), Ranunculaceae (up to $8 \%$ ), Polygonaceae (up to $4 \%$ ), Rumex (up to $8 \%$ ), Asteraceae (up to $7 \%$ ), Artemisia (up to $14 \%$ ), and Caryophyllaceae (up to $9 \%$ ). Among the spore taxa, Bryales percentages are the most dominant (up to $32 \%$ ). Values of Sphagnum and Selaginella rupestris are less than $5 \%$.

In the Arctic, where the vegetation cover has low pollen productivity, the spore-pollen spectra of modern and fossil plant communities are often characterized by a significant inclusion of pollen from plant species that are exotic to the Arctic and carried long distances by the wind. Therefore, for a more reliable interpretation of the spore-pollen spectra from the floodplain sediments, an analysis of the modern vegetation in the Bolshaya Kuropatoch'ya River basin and near the coast of the East Siberian Sea (about $71^{\circ} 05^{\prime} \mathrm{N}$ ) was carried out, accompanied by an herbarium collection. The herbarium included species such as Alopecurus alpinus, A. glaucus, Arctagrostis arundinaceae, A. latifolia, Arctophila fulva, Calamagrostis deschampsioides, $C$. holmii, $C$. lapponica, Deschampsia glauca, D. sucatschewii, Dupontia fischeri, Festuca brachyphylla, F. vivipara, Phippsia concinna, Poa alpigena, P. arctica, Puccinellia hauptiana, Carex concolor, Eriophorum russeolum, E. scheuchzeri, Luzula confuse, Salix arctica, S. boganidensis, S. fuscescens, S. polaris, S. pulchra, S. recuvigemmata, S. reptans, Betula exilis, Rumex arcticus, Cerastium maximum, Lychnis ajanensis, Stellaria ciliatosepala, S. edwardsii, Caltha arctica, Delphinium chamissonis, Ranunculus nivalis, $R$. pallasii, $R$. pygmaeus, $R$. turneri, Papaver nudicaule, $P$. paucistaminum, Descurainia sophioides, Saxifraga caespitosa, $S$. cernua, S. foliolosa, S. hieraciifolia, S. hirculus, S. nelsoniana, S. porsildiana, Dryas punctata, Potentilla uniflora, Rubus chamaemorus, Comarum palustre, Astragalus alpinus, Empetrum nigrum, Chamaenerion latifolium, Hippuris vulgaris, Ledum 


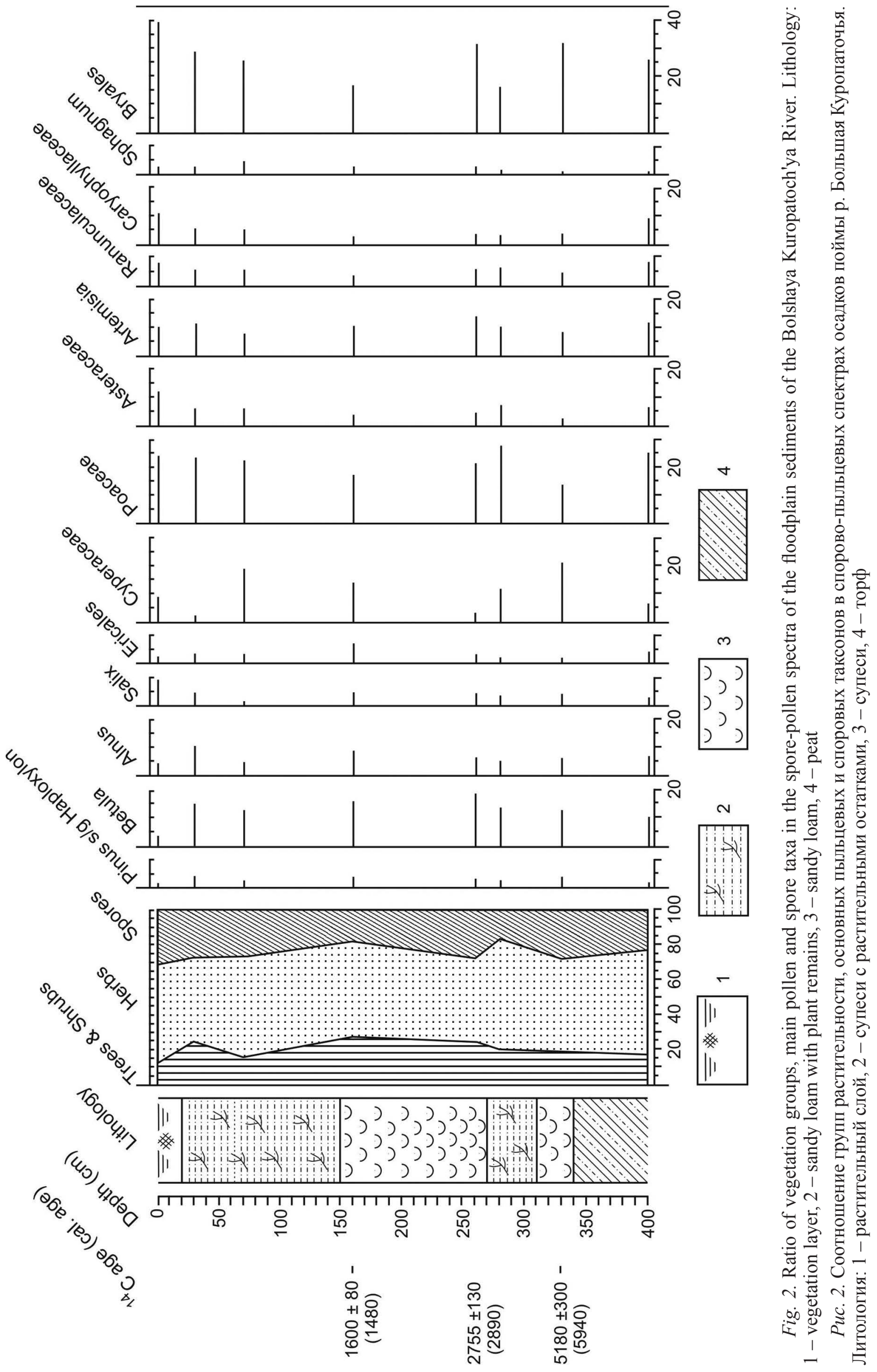




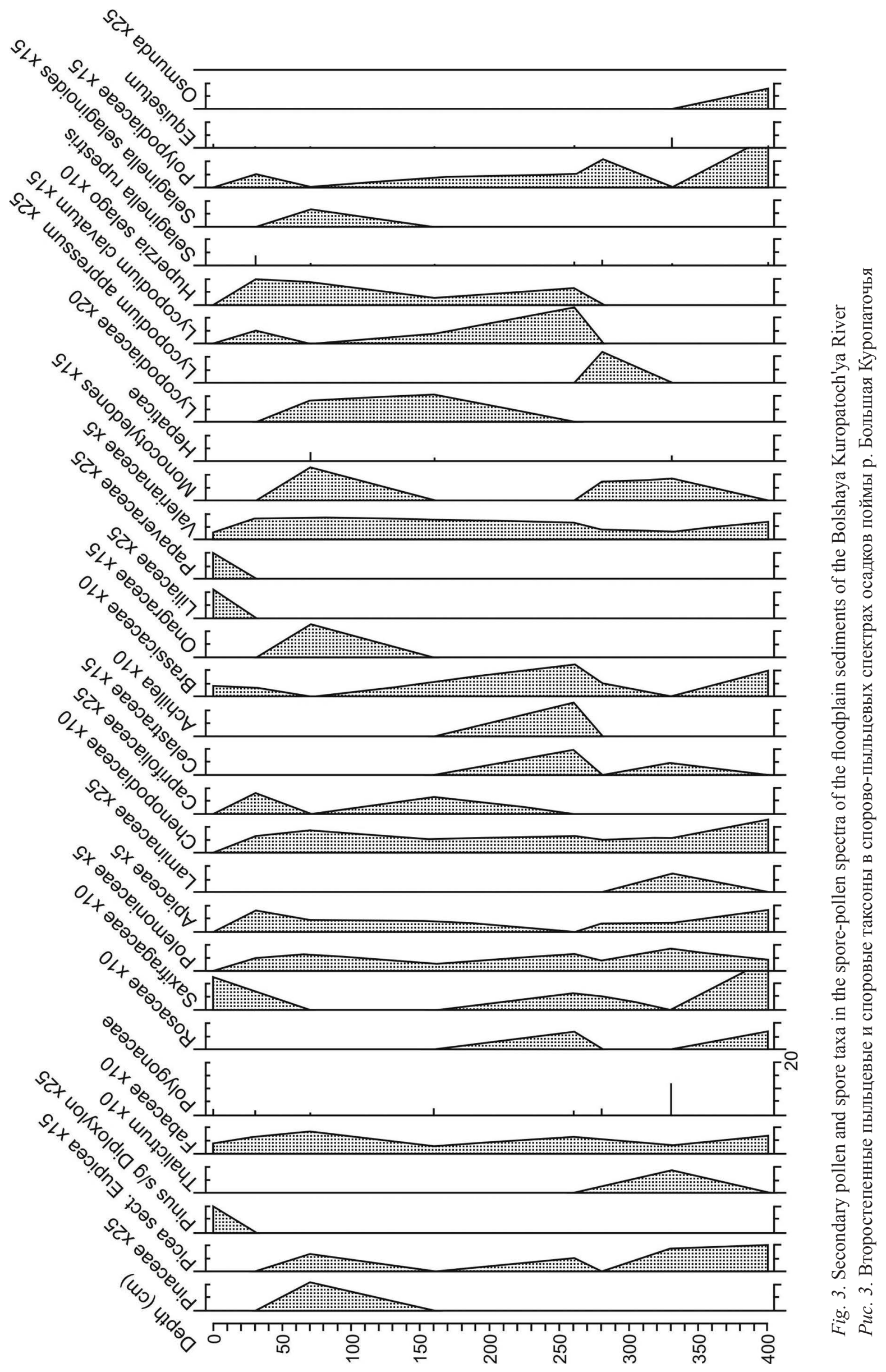


decumbens, Vaccinium uliginosum, V. vitis-idaea, Polemonium acutiflorum, Pedicularis oederi, $P$. sudetica, Valeriana capitata, Artemisia tilesii, Matricaria hookeri, Senecio atropurpureus, $S$. congestus, S. frigidus, S. subfrigidus, S. tundricola, and Taraxacum ceratophorum.

These species belong to 22 families: Poaceae (17 species), Cyperaceae (3 species), Juncaceae (1 species), Salicaceae ( 7 species), Betulaceae (1 species), Polygonaceae (1 species), Caryophyllaceae (4 species), Ranunculaceae (6 species), Papaveraceae (2 species), Brassicaceae (1 species), Saxifragaceae (7 species), Rosaceae (4 species), Fabaceae (1 species), Empetraceae (1 species), Onagraceae (1 species), Hippuridaceae (1 species), Ericaceae (1 species), Vaccinaceae (2 species), Polemoniaceae (1 species), Scrophulariaceae (2 species), Valerianaceae (1 species), and Asteraceae (8 species). Most families are represented in the spore-pollen diagrams (Fig. 2, 3). This list was supplemented with taxa found in the palynological analysis of the floodplain sediments: Caprifoliaceae, Apiaceae, Liliaceae, and Chenopodiaceae.

Thus, the analysis of modern vegetation in the Bolshaya Kuropatochya River basin when compared to the radiocarbon-dated palynological data clearly shows the presence by the latter part of the Middle Holocene of Betula-Salix shrub-herb tundra, a vegetation community like that found in the region today. The data further reflect the replacement of the Betula forest-tundra, which prevailed in the northern regions of Western Beringia in the Early
Holocene and included Duschekia fruticosa and large shrubs of Salix sp. Such dramatic changes in the vegetation cover not only reflect the hemispheric-wide reduction in summer insolation, but also can be linked to the rise in sea level, which approximated modern levels between 7.000-6.000 years ago (Klige, 1982). The greater proximity to the cool waters of the East Siberian Sea would have led to a decrease in the contrast of summer and winter temperatures and, thus, to a decrease in continentality in the regional climate and a significant reduction in the growing season in the northern coastal regions.

This work was supported by the Russian Foundation for Basic Research (project 19-0500477). We are grateful to Yu. A. Korzun and L. N. Kotova for help in preparing the materials.

\section{REFERENCES}

Kaplina, T. N., Lozhkin, A. V., 1979. Age of Alass Deposits of the Primorskaya Lowland of Yakutia, Izvestiya AN USSR, Geological Series. 2, 69-76 [In Russian].

Klige, R. K., 1982. Changes in the Ocean Level in the History of the Earth, Fluctuations in the Sea and Ocean Levels over 15.000 Years. Moscow, Nauka. 11-22 [In Russian].

Walker, M., Head, M. J., Lowe, J., Berkelhammer, M., Bjorck, S., Cheng, H., Cwynar, L. C., Fisger, D., Gkinis, V., Long, A., Newnham, R., Rasmussen, S. O., Weiss, H. 2019. Subdividing the Holocene Series / Epoch: Formalization of Stages/Ages and Subseries/Subepochs, and Designation of GSSPs and Auxiliary Stratotypes, Journal of Quaternary Science. 34, 173-186.

\title{
ВОЗРАСТ И ПАЛИНОЛОГИЧЕСКАЯ ХАРАКТЕРИСТИКА ПОЙМЕННЫХ ОТЛОЖЕНИЙ КОЛЫМСКОЙ НИЗМЕННОСТИ (Северо-Восток Сибири)
}

\author{
Ложкин А. В. ${ }^{1}$ Андерсон П. М. ${ }^{2}$
}

${ }^{\prime}$ ФГБУН Северо-Восточный комплексный научно-исследовательский институт им. Н. А. Шило ДВО РАН, г. Магадан

${ }^{2}$ Вашингтонский университет, факультет наук о Земле и Космосе, Центр четвертичных исследований, г. Сиэтл, США

Поймы рек, достигающие в ширину несколько километров, являются одним из основных элементов рельефа Колымской низменности. Их взаимоотношения с другими формами рельефа - едомой, аласами, фрагментами речных террас, прекрасно наблюдаются в бассейне р. Большая Куропаточья, пересекающей низменность в меридиональном направлении между $156^{\circ} 30^{\prime}$ и $157^{\circ} 15^{\prime}$ в. д. Первое радиоуглеродное датирование отложений поймы Колымской низменности было выполнено при исследовании обнажения на левобережье р. Большая Куропаточья в ее среднем течении $\left(71^{\circ} 40^{\prime}\right.$ с. ш., $156^{\circ} 45^{\prime}$ в. д.). Пойменные осадки, представленные чередованием слоев аллювиального алеврита и торфа общей мощностью 5 м, вскрыты здесь в обрывистом берегу старичного озера. Полученные датировки показывают, 
что начало формирования современной поймы р. Большая Куропаточья относится к концу среднего голоцена и продолжается в течение позднего голоцена до настоящего времени. Так как растительный покров арктических и субарктических районов характеризуется невысокой пыльцевой продуктивностью, спорово-пыльцевые спектры современных и ископаемых растительных сообществ нередко содержат повышенное количество пыльцы экзотических для Арктики растительных видов, принесенной ветром с дальних расстояний. Для более надежной интерпретации спорово-пыльцевых спектров пойменных осадков был выполнен анализ современной растительности в бассейне р. Большая Куропаточья и близ побережья Восточно-Сибирского моря (около $71^{\circ} 05^{\prime}$ с. ш.), сопровождавшийся гербарным сбором. Датированные по радиоуглероду палинологические данные определенно свидетельствуют о развитии во второй половине голоцена близкой современной Betula-Salix кустарниково-травянистой тундры. Она отражает смену господствовавшей в северных районах Западной Берингии в раннем голоцене березовой лесотундры с участием Duschekia friticosa, крупнокустарниковых видов Salix sp. Такие разительные изменения растительного покрова следует также связывать, очевидно, с поднятием уровня моря, который около 7 000-6 000 л. н. становится близким современному, что привело к снижению контрастности летних и зимних температур и, таким образом, уменьшению континентальности климата, существенному сокращению вегетационного периода в прибрежных районах ВосточноСибирского моря.

\section{Ключевые слова: голоцен, пойма, меандр, старица, осадки, радиоуглерод, палинология, растительность.}

\section{ЛИТЕРАТУРА}

Каплина Т. Н., Ложкин А. В. Возраст аласных отложений Приморской низменности Якутии // Известия АН СССР. Сер. геологическая. 1979. № 2. C. 69-76.

Клиге Р. К. Изменение уровня океана в истории Земли // Колебания уровней морей и океанов за 15000 лет. Москва : Наука, 1982. С. 11-22.
Walker M., Head M. J., Lowe J., Berkelhammer M., Bjorck S., Cheng H., Cwynar L. C., Fisger D., Gkinis V., Long A., Newnham R., Rasmussen S. O., Weiss H. Subdividing the Holocene Series / Epoch: formalization of stages/ages and subseries/subepochs, and designation of GSSPs and auxiliary stratotypes // Journal of Quaternary Science. 2019. Vol. 34. P. 173-186. 